\title{
Variation in the colour of the necrophagous fly, Prochyliza nigrimana (Diptera: Piophilidae): A case of seasonal polymorphism
}

\author{
DANIEl MARTÍN-VEGA and Arturo BAZ \\ Department of Zoology and Physical Anthropology, University of Alcalá, E-28871 Alcalá de Henares, Madrid, Spain; \\ e-mails: daniel.martinve@uah.es, arturo.baz@uah.es
}

Key words. Melanism, seasonal polymorphism, Piophilidae, Prochyliza nigrimana

\begin{abstract}
The occurrence of colour polymorphism in wild populations of the necrophagous fly Prochyliza nigrimana (Diptera: Piophilidae) is recorded but never treated in detail. The present paper shows that there is a seasonal distribution in the morphotypes, with the dark morphs emerging in spring and pale morphs emerging later and most abundant in summer. Furthermore, different proportions of each morph occur along altitudinal gradients, with dark morphs significantly more abundant at low altitudes, where mean temperatures are warmer than at high altitudes where the pale coloured morphs were more abundant. Explanations based on the adaptive value of thermal melanism are discussed.
\end{abstract}

\section{INTRODUCTION}

Melanism, the occurrence of individuals that are mostly or completely darkly pigmented, either as fixed differences between closely related species or as intraspecific polymorphisms (i.e. dark and pale morphs), is very common in the animal kingdom (Majerus, 1998; True, 2003). Majerus (1998) described melanism as "evolution in action" and cases of melanism in animals are commonly used as textbook examples of evolutionary dynamics. However, although melanism is common in many different animal taxa, it is perhaps most common in insects (Majerus, 1998) as most of the cited cases are of insects and the classical explanation of the adaptative mechanisms is based on industrial melanism in the peppered moth Biston betularia (L.) (Berry, 2008). Nevertheless, melanism in insects might be associated with diverse selective pressures and pleiotropic effects (Majerus, 1998; True, 2003), being often correlated with regulatory changes in both transcription factor genes and structural genes (Wittkopp et al., 2003). Ultimately, the precise ecological and developmental genetic contexts of melanism in each species might be unique (True, 2003).

The occurrence of dark-pigmented individuals in wild populations of Prochyliza nigrimana (Meigen, 1826) (Diptera: Piophilidae) is mentioned in several publications (e.g. Zuska \& Laštovka, 1965; Merz, 1996) but it is not treated in detail, although it has caused problems of synonymy (Steyskal, 1968) and controversy over the identity of Prochyliza nigricornis (Meigen, 1826) (see Discussion), a rare European species. Prochyliza nigrimana is widespread throughout the Holarctic and Neotropical Regions and in common with most of the Piophilidae its larvae feed predominantly on carrion, but also on proteinaceous animal matter, which can be damaging for the food industry. Furthermore, there are records of this species developing on rotten fruit and decaying leaves (Zuska \& Laštovka, 1965). Regarding its presence on carrion, $P$. nigrimana is frequently attracted to carcasses in advanced stages of decay and is recorded in some carrion-insects succession studies (e.g. MartínVega et al., 2010; Prado e Castro \& García, 2010).

\section{MATERIAL AND METHODS}

A survey using carrion-baited traps was carried out at different localities to study the ecology of sarcosaprophagous insects in natural habitats in central Spain. The carrion-baited traps were a modified version of the traps used by Morón \& Terrón (1984), which were baited with squid as in previous studies (for more details see Baz et al., 2007).

Localities were selected based on a stratified sampling regime taking into account the following variables: bioclimatical levels, forest type and soil type. This resulted in the selection of 7 main types of natural habitat, which are distributed throughout the whole Madrid province in central Spain: (1) mesomediterranean holm oakwood (Quercus ilex ssp. ballota) on limestone (MHL); (2) id. on gypsum and marlstone (MHGy); (3) id. on sand (MHS); (4) id. on granite (MHG); (5) supramediterranean holm oakwood on granite (SHG); (6) supramediterranean oakwood (Quercus pyrenaica) on granite and schist (SOGS); (7) oromediterranean Scot's pine forests (Pinus sylvestris) on granite and schist (OPGS). Three localities for each habitat were selected, which resulted in a total 21 sites. Detailed information on the location and bioclimatic features of these sites can be found in Baz et al. (2010). Three traps were set at each site and monitored from June 2006 to May 2007. Traps were operated for a period of seven days in each month. A total of 63 traps were set over the period of 12 months and at the end of this period there were 756 samples $(63$ traps $\times 12)$.

Specimens of $P$. nigrimana were identified using the keys of McAlpine (1977). Significant differences between frequencies of both dark and pale morphs were estimated by means of chisquare tests using a significance level of $\mathrm{P}<0.05$.

\section{RESULTS}

A total of 1052 individuals of P.nigrimana were collected from the carrion-baited traps. The specimens were easily distinguishable as either dark morphs, which had a 


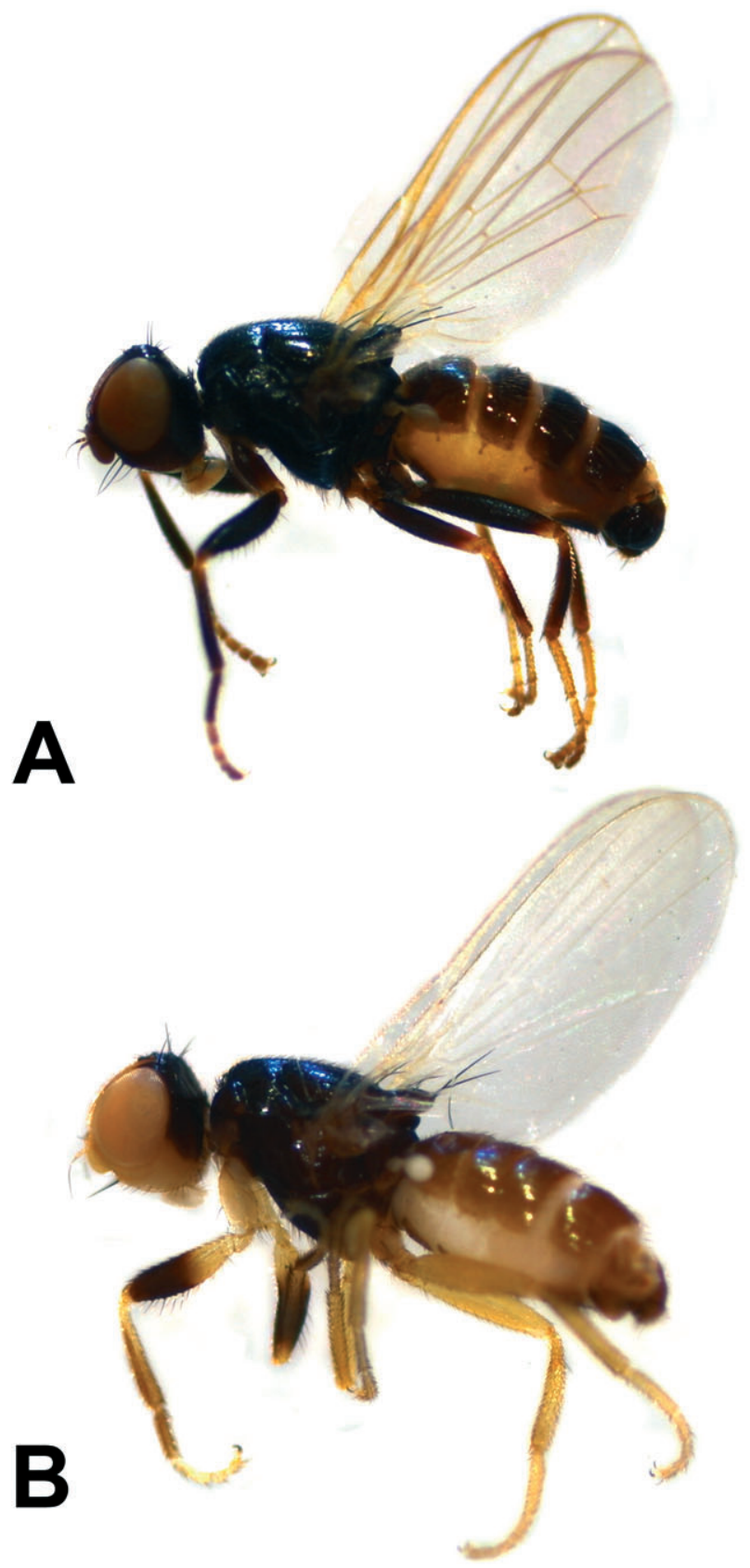

Fig. 1. Morphotypes of the piophilid Prochyliza nigrimana. A - dark morph, male; B - pale morph, male.

dark body coloration, with dark middle and posterior legs and anterior coxae partially darkened (Fig. 1A), or pale morphs, which had a pale body coloration, with middle legs, posterior legs and anterior coxae entirely yellow (Fig. 1B). Of the total number of specimens collected 145 were dark and 907 pale coloured.

Table 1 gives the numbers of both the dark and pale morphs caught in each month and habitat. There were significant differences in the catches at every habitat except the mesomediterranean holm oakwood on gypsum and marlstone (MHGy). In supra-mediterranean habitats a significantly higher number of the dark morph were caught in holm oakwood (SHG) and a significantly lower number in oakwood (SOGS). Fig. 2 shows the proportion of each capture made up of each morph in each habitat.

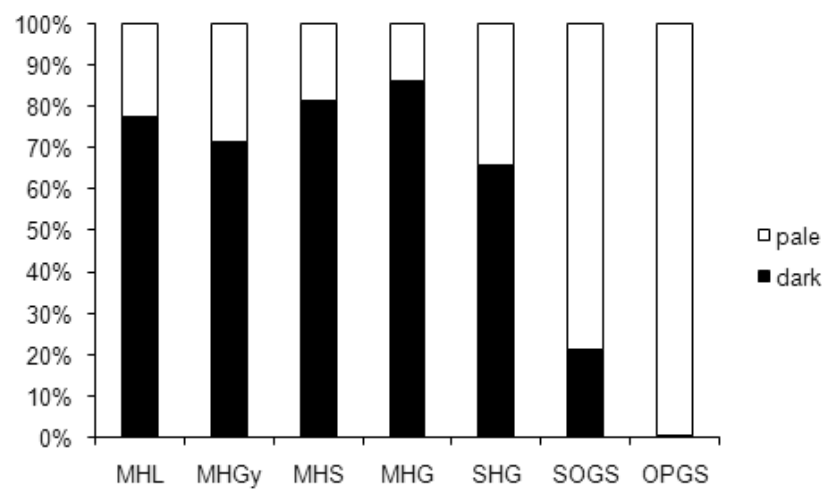

Fig. 2. The percentage of dark morphs (black bars) and pale morphs (white bars) caught in each habitat. Abbreviations for the habitats are given in Material and methods.

In terms of the monthly captures, only pale morphs were collected from June to October, with the higher numbers collected in oromediterranean Scot's pine forests on granite and schist (OPGS) between June and July (Table 1, Fig. 3). Most of the dark morphs were collected in April. May was the only month in which both dark and pale morphs were collected (Table 1, Fig. 3).

\section{DISCUSSION}

Current data seem to indicate seasonality in the occurrence of the different colour morphs of $P$. nigrimana: dark morphs were collected almost exclusively in April, while pale morphs appear later, in May, and were most abundant in June and July (Fig. 3). As the present data is only for one year it is not possible to be sure of the periodicity of this seasonal pattern, however, the changes in frequencies of the colour morphs seem to be cyclic, as predicted by some theories and observed in several insect populations (Zvereva et al., 2002; Svensson \& Abbott, 2005). Furthermore, other surveys, using the same methodology and carried out in several natural habitats in central Spain between June and September in 2003 and 2007 (see Baz et al., 2010 for details), collected many pale individuals of $P$. nigrimana but no dark morphs (unpubl. data). In addition, the occurrence of dark-pigmented individuals may be under reported because of the wide varia-

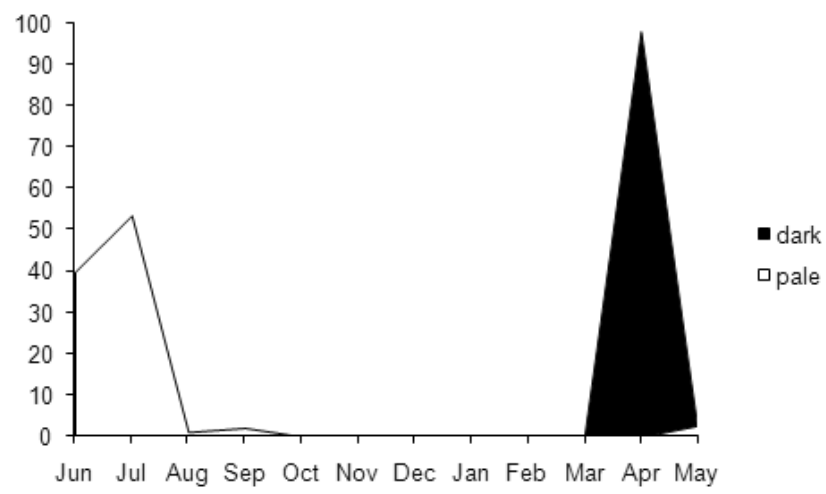

Fig. 3. Captures each month of dark morphs (black area) and light morphs (white areas), expressed as percentages of the total number of individuals collected. 
TABLE 1. Numbers of each colour morph caught each month in each habitat, with values of the $\chi^{2}$ test and levels of significance. D - dark morph, P pale morph. Abbreviations for the habitats are given in Material and methods.

\begin{tabular}{|c|c|c|c|c|c|c|c|c|c|}
\hline & & MHL & MHGy & MHS & MHG & SHG & SOGS & OPGS & Total \\
\hline \multirow{2}{*}{ June } & $\mathrm{D}$ & 0 & 0 & 0 & 0 & 0 & 0 & 0 & 0 \\
\hline & $\mathrm{P}$ & 0 & 0 & 0 & 0 & 0 & 18 & 343 & 361 \\
\hline \multirow{2}{*}{ July } & $\mathrm{D}$ & 0 & 0 & 0 & 0 & 0 & 0 & 0 & 0 \\
\hline & $\mathrm{P}$ & 0 & 0 & 0 & 0 & 2 & 31 & 454 & 487 \\
\hline \multirow{2}{*}{ August } & $\mathrm{D}$ & 0 & 0 & 0 & 0 & 0 & 0 & 0 & 0 \\
\hline & $\mathrm{P}$ & 0 & 0 & 0 & 0 & 3 & 3 & 5 & 11 \\
\hline \multirow{2}{*}{ September } & $\mathrm{D}$ & 0 & 0 & 0 & 0 & 0 & 0 & 0 & 0 \\
\hline & $\mathrm{P}$ & 4 & 1 & 2 & 0 & 13 & 0 & 0 & 20 \\
\hline \multirow{2}{*}{ October } & $\mathrm{D}$ & 0 & 0 & 0 & 0 & 0 & 0 & 0 & 0 \\
\hline & $\mathrm{P}$ & 0 & 1 & 0 & 0 & 0 & 0 & 0 & 1 \\
\hline \multirow{2}{*}{ April } & $\mathrm{D}$ & 14 & 5 & 31 & 31 & 47 & 14 & 0 & 142 \\
\hline & $\mathrm{P}$ & 0 & 0 & 0 & 0 & 0 & 0 & 0 & 0 \\
\hline \multirow{2}{*}{ May } & $\mathrm{D}$ & 0 & 0 & 0 & 0 & 1 & 0 & 2 & 3 \\
\hline & $\mathrm{P}$ & 0 & 0 & 5 & 5 & 2 & 0 & 10 & 25 \\
\hline \multirow{2}{*}{ Total } & $\mathrm{D}$ & 14 & 5 & 31 & 31 & 48 & 14 & 2 & 145 \\
\hline & $\mathrm{P}$ & 4 & 2 & 7 & 5 & 25 & 52 & 812 & 907 \\
\hline$\chi^{2}$ & & 5.55 & 1.28 & 15.15 & 18.77 & 7.24 & 21.87 & 806.02 & 551.94 \\
\hline $\mathrm{P}$ & & $<0.05$ & n.s. & $<0.01$ & $<0.01$ & $<0.01$ & $<0.01$ & $<0.01$ & $<0.01$ \\
\hline
\end{tabular}

tion in general body colour in $P$. nigrimana and because some authors consider that this species and Prochyliza nigricornis should be synonymized (e.g. Steyskal, 1968; Merz, 1996; Ozerov, 2004). This is a consequence of the fact that the diagnostic characters of these species are only based on body colour, with $P$. nigricornis even darker than the dark morphs of $P$. nigrimana and with front coxae, cheek, face, palpi and antennae wholly black (McAlpine, 1977). Because of this, it is suggested that $P$. nigricornis is simply an extreme colour variant of $P$. nigrimana (Steyskal, 1968). However, both species show differences, not only in body colour, but also in the morphology of head and scutellum (Zuska \& Laštovka, 1965; Merz, 1996; Stubbs \& Chandler, 2001). Recently some specimens were recorded from central Spain with the colour ascribed to $P$. nigricornis (Martín-Vega \& Baz, 2010). Comparison of the morphological characters and male genitalia of these specimens of $P$. nigricornis with that of both morphotypes of $P$. nigrimana revealed some differences (Martín-Vega \& Baz, pers. obs.), so it is considered that they are distinct species.

An earlier eclosion of dark morphs compared to pale morphs is recorded for other insect species (True, 2003), as is the faster darkening of the cuticle of dark morphs (Thompson et al., 2002). The emergence of dark morphs of $P$. nigrimana in early spring and a later eclosion of pale morphs accords with the theory of thermal melanism, which states that dark morphs are favoured in cold conditions because they are more efficient at absorbing solar radiation (Brakefield, 1984). Conversely, pale morphs could be at an advantage in summer, when temperatures are higher and the hours of bright sunshine longer and therefore the overheating of dark morphs more likely to occur (Clusella Trullas et al., 2007). This is supported by the negative correlation between hours of bright sunshine and the frequency of dark morphs in the ladybird beetle Adalia bipunctata (L.) (Brakefield, 1984). Furthermore, it is suggested that seasonal polyphenism, i.e. the annual patterns in phenotypic ratios in successive generations are under some kind of environmental control (Shapiro, 1976) and typically induced by a change in photoperiod, with insects developing alternative phenotypes depending on whether the photoperiod they experience is longer or shorter than some critical day length (Nijhout, 2003).

There were also differences in the abundance of each morph at the three bioclimatical levels sampled (Fig. 2). Such differences may be due to the altitude of each of the bioclimatical levels, in particular the temperatures at these altitudes (Rivas-Martínez et al., 1987). Thus, the activity of dark morphs in early spring is possible at the lower localities in the mesomediterranean and supramediterranean levels, with the temperatures apparently too low at the highest localities of the oromediterranean level (Table 1). In fact, April mean temperatures are $11^{\circ} \mathrm{C}$ and $9.5^{\circ} \mathrm{C}$ at the mesomediterranean and supramediterranean localities, respectively, and $5.6^{\circ} \mathrm{C}$ at the oromediterranean localities (Ninyerola et al., 2005). In contrast, June and July mean temperatures are respectively $20^{\circ} \mathrm{C}$ and $24^{\circ} \mathrm{C}$ at the mesomediterranean level localities, which may be too warm even for the pale morph. The summer temperatures at this bioclimatical level in central Spain appear to be unfavourable for Piophilid species (Martín-Vega et al., 2010). Consequently, in summer pale morphs are more abundant at localities in the supramediterranean and oromediterranean levels (Table 1), where the June mean temperatures are, respectively, $18^{\circ} \mathrm{C}$ and $14.6^{\circ} \mathrm{C}$ and July mean temperatures, $21.3^{\circ} \mathrm{C}$ and $18.6^{\circ} \mathrm{C}$ (Ninyerola et al., 2005).

As different proportions of each morph of $P$. nigrimana were recorded along an altitudinal gradient it is possible that this species could be used as a bioindicator of global warming in Mediterranean mountain areas. One of the best places to look for changes in plant and animal life resulting from climate change is in the mountains, where the gradual warming over the last few years has affected the distribution of some necrophagous insects (Turchetto $\&$ Vanin, 2010). If temperature determines the time of emergence of adults, then it can be assumed that a pro- 
gressive increase in temperature in mountainous areas would lead to an advance in the time of emergence of adults and therefore an increase in the proportion of dark individuals. From this point of view, monitoring populations and the relative abundance of each of the two morphs of $P$. nigrimana in mountain areas could provide a measure of small changes in the climate in the area.

Unfortunately, there is a lack of information on the population dynamics, voltinism and longevity of $P$. nigrimana. Moreover, diverse selective pressures and correlated or pleiotropic effects might be associated with melanism in insects and often more than one ecological mechanism affects melanism in a particular species (see True, 2003, for a review), so it is difficult to specify the ecological context in the present case. Earlier emergence times could benefit dark morphs with an increased mating success (True, 2003), which would compensate for the increased costs associated with the production of melanin (Thompson et al., 2002). Conversely, there must be a compensatory fitness advantage to having a paler cuticle and emerging later, but the nature of this advantage remains unclear (Thompson et al., 2002). On the other hand, theory indicates that different times of emergence introduce frequency dependant factors maintaining polymorphism (Mani, 1981) and a phenotype induced by a change in the environment can be moulded into an adaptative phenotype through quantitative genetic changes (Suzuki \& Nijhout, 2006). Perhaps further and long-term studies on the dark pigmentation in $P$. nigrimana may throw some light on this issue.

ACKNOWLEDGEMENTS. We are grateful to two anonymous reviewers for their comments and suggestions for improving the manuscript. This work was funded by the Spanish Ministerio de Ciencia y Tecnología (Research Project BOS2003-00400) and the University of Alcalá (Research Project PI2003/016). The authors are members of the IUICP (Instituto Universitario de Investigación en Ciencias Policiales) of the University of Alcalá.

\section{REFERENCES}

Baz A., Cifrián B., Díaz-Aranda L.M. \& Martín-Vega D. 2007: The distribution of the adult blow-flies (Diptera: Calliphoridae) along an altitudinal gradient in central Spain. Ann. Soc. Entomol. Fr. 43: 289-296.

Baz A., Cifrián B., Martín-Vega D. \& Baena M. 2010: Phytophagous insects captured in carrion-baited traps in central Spain. Bull. Insectol. 63: 21-30.

BERRY R.J. 2008: Industrial melanism and peppered moths (Biston betularia (L.)). Biol. J. Linn. Soc. 39: 301-322.

BRAKEFIELD P.M. 1984: Ecological studies on the polymorphic ladybird Adalia bipunctata in the Netherlands. II. Population dynamics, differential timing of reproduction, and thermal melanism. J. Anim. Ecol. 53: 775-790.

Clusella Trullas S., van Wyk J.H. \& Spotilla J.R. 2007: Thermal melanism in ectotherms. J. Therm. Biol. 32: $235-245$.

Majerus M.E.N. 1998: Melanism: Evolution in Action. Oxford University Press, Oxford, $370 \mathrm{pp}$.

MANI G.S. 1981: Conditions for balanced polymorphism in the presence of differential delay in developmental time. Theor. Popul. Biol. 20: 363-393.
Martín-Vega D. \& Baz A. 2010: Prochyliza nigricornis (Meigen, 1826) (Diptera: Piophilidae): nueva especie para la fauna de la Península Ibérica. Bol. Asoc. Esp. Entomol. 34: 249-251.

Martín-Vega D., Gómez-Gómez A., Baz A. \& Díaz-Aranda L.M. 2010: New piophilid in town: the first Palaearctic record of Piophila megastigmata and its coexistence with Piophila casei in central Spain. Med. Vet. Entomol. doi: 10.1111/j.1365-2915.2010.00907.x

McAlpine J.F. 1977: A revised classification of the Piophilidae, including 'Neottiophilidae' and 'Thyreophoridae' (Diptera: Schizophora). Mem. Entomol. Soc. Can. 103: 1-66.

Merz B. 1996: Die Piophilidae (Diptera) der Schweiz mit Beschreibung einer neuen Art. Mitt. Schweiz. Entomol. Ges. 69: 345-360.

Morón M.A. \& TERRÓN R.A. 1984: Distribución altitudinal y estacional de los insectos necrófilos en la Sierra Norte de Hidalgo, México. Acta Zool. Mex. (N.S.) 3: 1-47.

Nishout H.F. 2003: Development and evolution of adaptative polyphenisms. Evol. Dev. 5: 9-18.

Ninyerola M., Pons X. \& Roure J.M. 2005: Atlas Climático Digital de la Península Ibérica. Metodología y Aplicaciones en Bioclimatología y Geobotánica. Universidad Autónoma de Barcelona, Bellaterra, $44 \mathrm{pp}$.

Ozerov A.L. 2004: On the classification of the Family Piophilidae (Diptera). Zool. Zh. 83: 600-608 [in Russian, English abstr.].

Prado e Castro C. \& García M.D. 2010: Additions to the Piophilidae (Diptera) fauna from Portugal, with new records. Graellsia 66: 101-105.

Rivas-Martínez S., Gandullo Gutiérrez J.M., Allué Andrade J.L., Montero de Burgos J.L. \& González Rebollar J.L. 1987: Memoria del Mapa de Series de Vegetación de Espańa. ICONA, Madrid, 268 pp.

SHAPIRO A.M. 1976: Seasonal polyphenism. Evol. Biol. 9: 259-333.

StEYSKal G.C. 1968: Notes on North American Piophilidae. III. Proc. Entomol. Soc. Wash. 70: 25-27.

Stubbs A.E. \& Chandere P.J. 2001: A provisional key to British Piophilidae (Diptera) and Parapiophila flavipes (Zetterstedt, 1847) new to Britain. Dipterists Digest (2nd ser.) 8: 71-78.

SuZUKI Y. \& NiJHout H.F. 2006: Evolution of a polyphenism by genetic accommodation. Science 311: 650-652.

Svensson E.I. \& Аввотт J. 2005: Evolutionary dynamics and population biology of a polymorphic insect. J. Evol. Biol. 18: $1503-1514$.

Thompson J.J.W., Armitage S.A.O. \& Siva-Jothy M.T. 2002: Cuticular colour change after imaginal eclosion is timeconstrained: blacker beetles darken faster. Physiol. Entomol. 27: 136-141.

Turchetto M. \& VAnin S. 2010: Climate change and forensic entomology. In Amendt J., Goff M.L., Campobasso C.P. \& Grassberger M. (eds): Current Concepts in Forensic Entomology. Springer, Dordrecht, pp. 327-351.

TRUE J.R. 2003: Insect melanism: the molecules matter. Trends Ecol. Evol. 18: 640-647.

WittKopp P.J., Carroll S.B. \& Kopp A. 2003: Evolution in black and white: genetic control of pigment patterns in Drosophila. Trends Genet. 19: 495-504.

ZUSKa J. \& LAŠTOVKa P. 1965: A review of the Czechoslovak species of the family Piophilidae with special reference to their importance to food industry (Diptera, Acalyptrata). Acta Entomol. Bohemoslov. 62: 141-157.

Zvereva E.L., Kozlov M.V. \& Kruglova O.Yu. 2002: Colour polymorphism in relation to population dynamics of the leaf beetle, Chrysomela lapponica. Evol. Ecol. 16: 523-539.

Received August 2, 2010; revised and accepted October 1, 2010 